\title{
Hipersensibilidade e Necrose Sistêmica em Nicotiana benthamiana Transformada com o Gene de Resistência $S w-5$ de Tomateiro
}

\author{
Douglas Lau ${ }^{1}$, Julio Cezar F. de Oliveira ${ }^{2}$, Elene Y. Lau ${ }^{1} \&$ Sérgio H. Brommonschenkel ${ }^{1}$ \\ ${ }^{1}$ Departamento de Fitopatologia/Bioagro, Universidade Federal de Viçosa, CEP 36571-000, Viçosa, MG; \\ e-mail: shbromo@ufv.br; ${ }^{2}$ Departamento de Tecnologia, Universidade Estadual Paulista, CEP 14884-900, Jaboticabal, SP
}

(Aceito para publicação em 26/01/2006)

Autor para correspondência: Sérgio H. Brommonschenkel

LAU, D., OLIVEIRA, J.C.F., YAMAZAKI LAU, E. \& BROMMONSCHENKEL, S.H. Hipersensibilidade e necrose sistêmica em Nicotiana benthamiana transformada com o gene de resistência $S w-5$ de tomateiro. Fitopatologia Brasileira 31:247-253. 2006.

\section{RESUMO}

O gene $S w$-5 do tomateiro confere resistência a várias espécies de tospovírus e codifica uma proteína contendo domínios de ligação a nucleotídeos e repetições ricas em leucina. Tomateiros com $S w-5$ exibem reações necróticas nas folhas inoculadas com tospovírus. Estas reações e a estrutura da proteína Sw-5 indicam que a resistência ocorre por meio do reconhecimento do patógeno e desencadeamento da resposta de hipersensibilidade. A capacidade de $S w-5$ de conferir resistência a tospovírus em tabaco selvagem (Nicotiana benthamiana Domin.) foi avaliada em plantas transgênicas. Uma construção com a seqüência aberta de leitura de $S w-5$ e sua região 3' não-traduzida sob controle do promotor $35 \mathrm{~S}$ do CaMV foi utilizada para transformação de $N$. benthamiana via Agrobacterium tumefaciens. Plantas de progênies R1 foram inoculadas com um isolado de tospovírus e avaliadas quanto à ocorrência de reação de hipersensibilidade e resistência à infecção sistêmica. Em uma progênie com segregação 3:1 (resistente:suscetível), foi selecionada uma planta homozigota e sua progênie avaliada quanto ao espectro da resistência a tospovírus. Plantas com o transgene exibiram resposta de hipersensibilidade $48 \mathrm{~h}$ após a inoculação, sendo resistentes à infecção sistêmica. O fenótipo da resistência foi dependente do isolado viral e um isolado de Tomato chlorotic spot virus (TCSV) causou necrose sistêmica em todas as plantas inoculadas, enquanto que isolados de Groundnut ringspot virus (GRSV) e um isolado relacionado a Chrysanthemum stem necrosis virus (CSNV) ficaram restritos ao sítio de infecção. Comparações do espectro da resistência obtido neste trabalho com aquele observado em outros membros da família Solanaceae indicam que as vias de transdução de sinais e as respostas de defesa ativadas por Sw-5 são conservadas dentro desta família e polimorfismos genéticos nas vias de transdução de sinais ou em componentes das respostas de defesa podem resultar em diferentes níveis de resistência.

Palavras-chave adicionais: resistência a vírus, expressão heteróloga, transdução de sinais.

\begin{abstract}
Hypersensitive response and systemic necrosis in Nicotiana benthamiana transformed with the $S w-5$ resistance gene from tomato.

The tomato gene $S w-5$ confers resistance against tospovirus species and codes for a nucleotide binding site and leucine rich protein. Tomatoes with the $S w-5$ gene develop a necrotic reaction when mechanically inoculated with tospoviruses. The necrotic lesions on inoculated leaves of the resistant plants and the structure of the protein codified by $S w-5$ suggests that the resistance depends on recognition of the pathogen and activation of hypersensitive response (HR). The capacity of the $S w-5$ to confer resistance in wild tobacco (Nicotiana benthamiana) was evaluated in transgenic plants transformed by Agrobacterium tumefaciens. The Sw- 5 ORF and its own 3' UTR region were placed under 35S promoter control. Plants of R1 progenies were inoculated with tospovirus and evaluated for local and systemic symptoms. In one progeny with 3:1 (resistant:susceptible) segregation ratio a homozygous plant was selected and the resistance spectrum of its progeny was evaluated. Transgenic plants showed hypersensitive response $48 \mathrm{~h}$ after inoculations and were resistant to tospovirus infection. The resistance was isolate-specific and a Tomato chlorotic spot virus (TCSV) isolate caused systemic necrosis in the transformed plants, while Groundnut ringspot virus (GRSV) isolates and one Chrysanthemum stem necrosis virus (CSNV) related isolate was restricted to the inoculation site. Comparisons of the resistance spectrum with that observed in other members of the Solanaceae suggest that the signal transduction pathways and resistance responses triggered by Sw-5 are conserved in Solanaceae, and the genetic polymorphism in the signal transduction pathways or defense response components may result in different resistance levels.
\end{abstract}

Additional keywords: virus resistance, heterologous expression, signal transduction.

\section{INTRODUÇÃO}

Espécies do gênero Tospovirus (família Bunyaviridae) têm sido descritas como agentes causais de doenças em uma ampla gama de hospedeiros em regiões tropicais, subtropicais e de clima temperado (German et al., 1992). Entre as espécies de tospovírus descritas, Tomato spotted wilt virus (TSWV), Tomato chlorotic spot virus (TCSV), 
Groundnut ringspot virus (GRSV) e Chrysanthemum stem necrosis virus (CSNV) são capazes de infectar tomateiro (Lycopersicon esculentum L.) e outras solanáceas causando a doença conhecida como "vira-cabeça" (Kurozawa \& Pavan, 1997; Bezerra et al., 1999; Lima et al., 2002).

O gene $S w-5$ é originário do tomateiro selvagem Lycopersicon peruvianum (L.) Miller e confere resistência a várias espécies de tospovírus. Originalmente, a resistência mediada por $S w-5$ foi considerada dominante com penetrância incompleta (Stevens et al., 1992; Boiteux \& Giordano, 1993). Fenotipicamente, a resistência se manifesta pela ausência de sintomas, ou pelo aparecimento de lesões necróticas nas folhas inoculadas (Stevens et al., 1992). Estudos envolvendo enxertia sugerem que $S w-5$ atua contendo o vírus no sítio de infecção (Lau, 2001).

A proteína codificada por $S w-5$ possui 1246 aminoácidos e caracteriza-se pela presença de domínios de ligação a nucleotídeos (nucleotide binding site, NBS) e repetições ricas em leucina (leucine rich repeats, LRR) (Brommonschenkel et al., 2000). Estas características estruturais são típicas de proteínas envolvidas na resposta de resistência a fitopatógenos (Martin et al., 2003; Belkhadir et al., 2004). A proteína $S w-5$ faz parte de uma classe que inclui, entre outras, as proteínas Mi (Milligan et al., 1998), I2C (Ori et al., 1997), RPM1 (Grant et al., 1995), Prf (Salmeron et al., 1996) e Rx (Bendahmane et al., 1999), que conferem resistência a nematóides, fungos, bactérias e vírus, respectivamente.

Modelos propõem que as proteínas codificadas pelos genes $R$ podem atuar como receptores diretos ou indiretos de proteínas codificadas pelos patógenos ou ainda, como sensores detectando alterações celulares provocadas por proteínas do patógeno (Nimchuk et al., 2003; Belkhadir et al., 2004). Em consequência deste reconhecimento, a ativação de vias de transdução de sinais relacionadas a diversos mecanismos de defesa levam à restrição do patógeno no sítio de infecção (Baker et al., 1997; Somssich \& Hahlbroch, 1998). As estratégias de defesa de plantas a patógenos incluem o aumento intracelular da concentração de espécies reativas de oxigênio, a lignificação e o fortalecimento de paredes celulares, a produção de substâncias antimicrobianas como as fitoalexinas e a indução da expressão de proteínas relacionadas à patogênese (proteínas PR), bem como de moléculas sinalizadoras, como o ácido salicílico, responsáveis pela ativação de respostas de defesa em células adjacentes (Localized Acquired Resistance, LAR) e tecidos mais distantes do sítio primário de infecção na planta (Systemic Acquired Resistance, SAR) (Hutcheson, 1998; Durrant \& Dong, 2004). A resposta de resistência pode, muitas vezes, ser visualizada macroscopicamente na forma de lesões necróticas restritas ao sítio de infecção (Resposta de Hipersensibilidade, HR) (Hammond-Kosack \& Jones, 1996).

O gene $S w-5$ confere re sistência não apenas em espécies e cultivares de tomateiro, mas também em outras espécies da família Solanaceae como o fumo (Nicotiana tabacum L.) e a berinjela (Solanum melongena L.) (Brommonschenkel et al., 2000; Lau, 2001; Picoli, 2000), porém não é capaz de conferir resistência em alface
(Lactuca sativa L.) (Karasawa, 2001; Yamazaki, 2001). Em fumo, o espectro da resistência é mais restrito em comparação com tomateiro (Lau, 2001). A funcionalidade de um gene $R$ em sistema heterólogo é considerada evidência da conservação das vias de transdução de sinais ativadas por este gene. Ao menos em solanáceas, estas vias devem ser conservadas, conforme verificado pela funcionalidade do gene $N$ de fumo em tomate (Whitham et al., 1996), Pto de tomate em Nicotiana benthamiana Domin. (Rommens et al., 1995) e $C f-9$ de tomate em fumo e batata (Solanum tuberosum L.) (Hammond-Kosack et al., 1998). A conservação das vias de transdução de sinais pode estar restrita a plantas botanicamente relacionadas, sendo este fenômeno denominado funcionalidade taxonômica restrita (restricted taxonomic functionality, RTF) (Tai et al., 1999). Neste contexto, o objetivo deste trabalho foi verificar a funcionalidade do gene $S w-5$ em fumo selvagem ( $N$. benthamiana) e comparar o espectro da resistência com o observado em outras espécies de solanáceas.

\section{MATERIAL E MÉTODOS}

\section{Isolados virais e inoculação}

Os isolados de tospovírus V1-3 (TCSV) (AF282982), $\mathrm{Cb}$ (GRSV) (AF251271) e AL (GRSV) (AF513219) e V2-2 utilizados neste trabalho são originários do Brasil e fazem parte da coleção do Laboratório de Genética da Interação PlantaPatógeno (BIOAGRO/UFV), sendo sua identificação baseada no sequenciamento do gene $N$ (nucleocapsídeo). O gene $N$ do isolado V2-2 foi apenas parcialmente sequenciado (seqüência não depositada no GenBank), sendo este isolado relacionado à espécie CSNV (79\% de identidade, 450nts) (Lau, 2001).

Para fins de inoculação, o inóculo original, mantido a $-80{ }^{\circ} \mathrm{C}$, foi previamente multiplicado em plantas de $N$. tabacum 'Havana 425'. Folhas infectadas foram maceradas em tampão fosfato de potássio $0,1 \mathrm{M}, \mathrm{pH} 7,0$, contendo sulfito de sódio $0,01 \mathrm{M}$ e carborundum 600 mesh. $\mathrm{O}$ extrato foi esfregado sobre folhas de plantas sadias de $N$. benthamiana com auxílio de gaze.

Após a inoculação, as plantas foram mantidas em casa de vegetação ou câmara de crescimento e avaliadas a cada dois dias por um período de 14 dias, observando-se o desenvolvimento de sintomas locais e sistêmicos.

\section{Transformação genética de $N$. benthamiana}

Fragmentos foliares de $N$. benthamiana foram transformados via Agrobacterium tumefaciens com o clone pGPP63. Este clone é constituído da estirpe desarmada LBA4404 de A. tumefaciens contendo o vetor binário pBI121, no qual o gene GUS foi substituído pela seqüência aberta de leitura (open reading frame, ORF) do gene $S w$ 5 (oriunda da linhagem SW99-1 de L. esculentum). Nesta construção a ORF Sw-5 está sob o controle do promotor $35 \mathrm{~S}$ do CaMV (Cauliflower mosaic virus) e contém a sua respectiva região 3' não-traduzida (3'NTR) (Figura 1) (Lima, 2001; Yamazaki, 2001). 


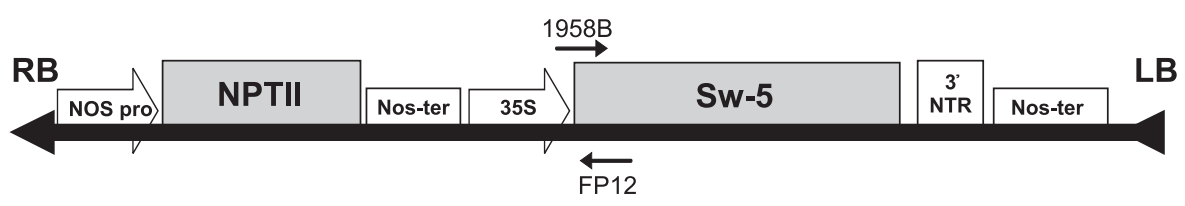

FIG. 1 - Representação diagramática do T-DNA da construção pGPP63, derivada do vetor pBI121. RB, borda direita; NOS pro, promotor do gene nos de Agrobacterium tumefaciens; NPT II, gene da neomicina fosfotransferase II, que confere resistência a canamicina; NOS ter, terminador do gene nos; 35S, promotor do RNA 35S do CaMV; Sw-5, ORF Sw-5; 1958B e FP12, oligonucleotídeos que pareiam na região 5' do gene $S w-5$; 3'NTR, região 3' não traduzida do gene $S w-5$; LB, borda esquerda.

\section{Determinação da presença do transgene}

A presença do gene $S w-5$ nas plantas transformadas foi determinada via PCR, utilizando-se oligonucleotídeos específicos para a seqüência transgênica. O DNA das plantas foi extraído de acordo com protocolo de Fulton et al. (1995). A reação de PCR consistiu em 100-200 ng de DNA genômico, $10 \mathrm{mM}$ Tris- $\mathrm{HCl} \mathrm{pH} 8,3,50 \mathrm{mM} \mathrm{KCl}, 1,5$ $\mathrm{mM} \mathrm{MgCl}, 0,1 \mathrm{mM}$ de cada um dos desoxinucleotídeos (dATP, dTTP, dCTP e dGTP), 10 pmoles de cada um dos oligonucleotídeos 1958B (5'-GGT GAA CTT CCC GGG AGA AAA TGG CTG-3') e FP12 (5'-AGG ATT TGT AGT ACG TCT CAA CTT G-3'), 2 a 5 unidades da enzima Taq DNA polimerase e água estéril (Milli-Q) para atingir um volume final de $25 \mu \mathrm{L}$. Os oligonucleotídeos 1958B e FP12 anelam na região 5' do gene $S w$-5 (Figura 1), permitindo a amplificação de uma sequência de $1125 \mathrm{pb}$. Após desnaturação inicial a $94{ }^{\circ} \mathrm{C}$ por 3 min, a amplificação constituiu-se de 40 ciclos de desnaturação por 30 segundos a $94{ }^{\circ} \mathrm{C}$, anelamento por $1 \mathrm{~min}$ a $52^{\circ} \mathrm{C}$ e extensão a $72{ }^{\circ} \mathrm{C}$ por $2 \mathrm{~min}$, com uma extensão final a $72^{\circ} \mathrm{C}$ por $5 \mathrm{~min}$. O produto da reação foi visualizado sob luz ultravioleta após corrida eletroforética a $90 \mathrm{~V}$ por $2 \mathrm{~h}$ em gel de agarose $1 \%$ (TAE $1 \mathrm{X}$ ) contendo brometo de etídeo.

\section{Análise de segregação e funcionalidade do transgene}

As plantas transformadas (R0) foram inoculadas com o isolado V2-2. Aquelas que exibiram reações locais necróticas e não manifestaram sintomas sistêmicos (portanto consideradas resistentes) foram autofecundadas. As sementes oriundas da autofecundação das plantas R0 que exibiram HR foram coletadas e utilizadas nos experimentos de análise de segregação. Aproximadamente 20 plantas de cinco progênies R1 foram inoculadas com o isolado V2-2 e avaliadas quanto à ocorrência de HR nas folhas inoculadas, até seis dias após a inoculação. O ajuste das proporções de plantas resistentes: suscetíveis ao modelo genético hipotetizado foi avaliado pelo teste do qui-quadrado $\left(\chi^{2}\right)$. Plantas resistentes de uma progênie que apresentou segregação indicativa de uma única inserção foram autofecundadas e as progênies R2 foram inoculadas, visando identificar plantas R1 homozigotas. Uma planta R1 homozigota foi selecionada e o espectro da resistência avaliado em sua descendência mediante a inoculação com quatro isolados de tospovírus (V1-3, Cb, AL e V2-2).

\section{RESULTADOS}

Transformação genética de $N$. benthamiana e análise de segregação do transgene

Dos 20 transformantes primários (R0) aclimatados em casa-de-vegetação e inoculados com o isolado viral V2-2, três apresentaram sintomas idênticos às plantas não transformadas de $N$. benthamiana, consistindo em lesões cloróticas em anel no sítio de inoculação e infecção sistêmica caracterizada por clorose e necrose nas nervuras. Dezessete plantas manifestaram reações locais típicas de HR. Destas plantas, porém, 11 manifestaram sintomas sistêmicos até a época do florescimento. Estes sintomas foram de natureza necrótica, diferindo dos sintomas observados em plantas não transformadas.

Cincoprogênies R1, geradas a partirda autofecundação de plantas R0 que não sofreram infecção viral sistêmica, foram avaliadas quanto à segregação da resistência. Considerando o nível de significância de $5 \%$ pelo teste de $\chi^{2}$, as progênies oriundas de B2, B5 e B9 apresentaram padrão de segregação indicativo de uma única inserção do transgene (Tabela 1). Baseado na segregação da resistência em progênies R2 uma planta R1 homozigota (todos os descendentes resistentes) foi selecionada (B5-5) e sua progênie utilizada nos ensaios de determinação do espectro da resistência. Por meio de PCR, utilizando os oligonucleotídeos 1958B e FP12, foi amplificado um fragmento de $1125 \mathrm{pb}$ correspondente à região 5' do gene $S w-5$, confirmando a presença do transgene em B5-5 (Figura 2).

\section{Análise do espectro da resistência}

A progênie da planta homozigota B5-5 foi inoculada com os quatro isolados de tospovírus. Das 40 plantas avaliadas (dez para cada isolado), todas exibiram sintomas locais necróticos dois dias após a inoculação (Figura $3 \mathrm{~B}$, Tabela 2). As lesões induzidas pelo isolado V1-3 apresentaram um aspecto distinto das demais, não sendo tão evidentes e alternando regiões necróticas com áreas cloróticas. Nas plantas não transformadas, os sintomas locais típicos da infecção viral só foram observados sete dias após a inoculação. Estes foram de natureza clorótica, muitas vezes na forma de anéis concêntricos (Figura 3A). Dez dias após a inoculação, todas as plantas não transformadas exibiam sintomas sistêmicos típicos de infecção por 
TABELA 1 - Segregação da resistência ao isolado de tospovírus V2-2 em progênies oriundas da autofecundação de plantas de $N$. benthamiana transformadas com a construção pGPP63

\begin{tabular}{|c|c|c|c|c|c|c|c|}
\hline \multirow[t]{2}{*}{ Progênie } & \multicolumn{2}{|c|}{$\begin{array}{c}\text { Fenótipos } \\
\text { Observados* }\end{array}$} & \multirow[t]{2}{*}{ Hipótese** } & \multicolumn{2}{|c|}{$\begin{array}{c}\text { Proporção } \\
\text { esperada }\end{array}$} & \multirow[t]{2}{*}{$\chi^{2}$} & \multirow[t]{2}{*}{$P \%$} \\
\hline & $\mathbf{R}$ & $\mathrm{S}$ & & $\mathbf{R}$ & S & & \\
\hline B2 & 15 & 5 & $3: 1$ & 15 & 5 & 0 & 100 \\
\hline B5 & 15 & 5 & $3: 1$ & 15 & 5 & 0 & 100 \\
\hline B9 & 12 & 8 & $3: 1$ & 15 & 5 & 2,4 & 12,13 \\
\hline B13 & 8 & 11 & $3: 1$ & 14,25 & 4,75 & 10,97 & 0,09 \\
\hline B18 & 9 & 8 & $3: 1$ & 12,75 & 4,25 & 4,41 & 3,57 \\
\hline
\end{tabular}

*R - presença de HR nas folhas inoculadas; $\mathrm{S}$ - ausência de HR nas folhas inoculadas.

**Considerando uma inserção do transgene e dominância completa.

tospovírus: clorose no limbo e nervuras, leve necrose em alguns pontos da haste e deformação foliar (Figura 3D). Nas plantas transformadas houve diferenças quanto à capacidade de restrição da infecção sistêmica dos diferentes isolados. Plantas inoculadas com os isolados V2-2, AL e $\mathrm{Cb}$ apresentaram apenas sintomas locais, enquanto todas as plantas inoculadas com o isolado V1-3 apresentaram sintomas sistêmicos (Figura 3C, Tabela 2), de natureza necrótica e, portanto, diferentes daqueles observados em plantas não transformadas.

\section{DISCUSSÃO}

O gene $S w-5$ do tomateiro foi funcional em $N$. benthamiana. Esta funcionalidade foi evidenciada por dois aspectos que diferenciam as plantas transformadas das não transformadas: presença de lesões locais necróticas nas folhas inoculadas e capacidade de contenção do vírus no sítio primário de infecção. Lesões necróticas no sítio de infecção, visualizadas pouco tempo após a inoculação, caracterizam a resposta de hipersensibilidade, um fenômeno que envolve o reconhecimento de elicitores do patógeno e a ativação de vias de transdução de sinais que conduzem às respostas de defesa da planta (Staskawicz et al., 1995; Nimchuk et al., 2003).

A funcionalidade da construção pGPP63 em $N$. benthamiana, em acordo com resultados obtidos em fumo (Yamazaki, 2001), demonstra que a ORF do gene $S w$ 5 utilizada na transformação contém toda a informação necessária à codificação de uma proteína capaz de ativar o processo de defesa. Assim, as seqüências de DNA adjacentes à ORF presentes no clone cosmídeo TC134-8 (inserto de aproximadamente $20 \mathrm{~Kb}$ ), utilizado anteriormente na transformação de plantas de tomate, fumo e berinjela (Brommonschenkel et al., 2000; Picoli, 2000), não são requeridas para o desencadeamento da resposta de hipersensibilidade e resistência a tospovírus.

A funcionalidade de $S w-5$ em $N$. benthamiana indica que as vias de sinalização e os mecanismos de defesa ativados pela proteína de resistência estão presentes nesta planta. Além do tomateiro, planta da qual o gene foi clonado, esta é a terceira espécie na qual se demonstra a conservação das

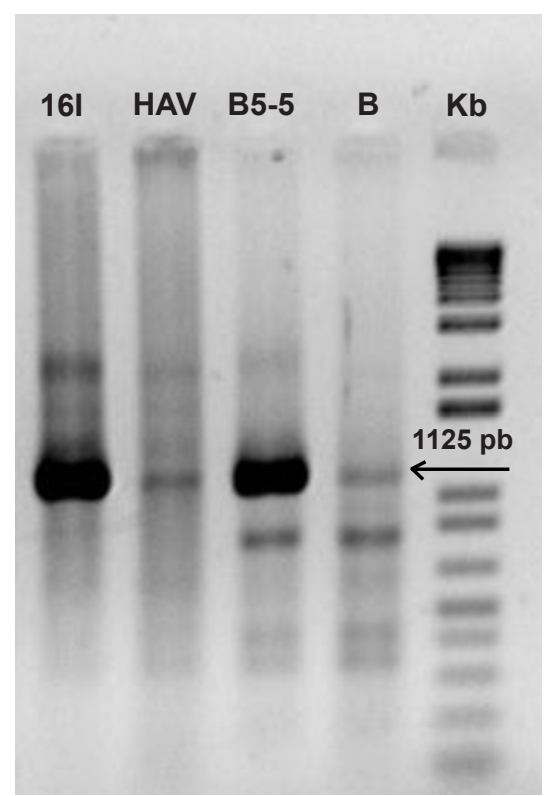

FIG. 2 - Confirmação da presença de $S w-5$ em B5-5 por meio de PCR. A presença do transgene foi verificada utilizando-se os oligonucleotídeos 1958B e FP12 que pareiam na região 5' do transgene. 16I, linhagem de Nicotiana tabacum com o clone cosmídeo TC134-8 que contém o gene $S w-5$; HAV, planta de $N$. tabacum não transformada; B5-5, planta de $N$. benthamiana transformada com o clone pGPP63. B, planta de $N$. benthamiana não transformada; Kb, marcador $1 \mathrm{~Kb}$ Plus DNA Ladder.

vias de defesa ativadas por $S w-5$. As outras duas espécies nas quais $S w-5$ foi funcional, $N$. tabacum e berinjela (Lau, 2001; Spassova et al., 2001; Picoli, 2000), também pertencem à família Solanaceae. Esta conservação pode ser restrita a esta família, uma vez que plantas de alface (família Asteraceae) transformadas com este gene são suscetíveis a tospovírus (Karasawa, 2001; Yamazaki, 2001). A conservação das vias de defesa dentro da família Solanaceae está bem demonstrada para outros genes de resistência, os quais foram transferidos para outras espécies por meio de transformação estável: gene $N$ de fumo para tomate (Whitham et al., 1996), Pto de tomate para $N$. benthamiana e $N$. tabacum (Rommens et al., 1995; Thilmony et al., 1995), $C f-9$ de tomate para fumo e batata (Hammond-Kosack et al., 1998) e Bs2 de pimentão para tomate (Tai et al., 1999). Técnicas de expressão transiente demonstraram que os genes $B s 2$ de pimentão e $C f-4$ e $C f-9$ de tomateiro são capazes de induzir resposta de hipersensibilidade em diversas solanáceas (Tai et al., 1999; Van der Hoorn et al., 2000).

A conservação dos componentes das vias de defesa ativadas por um gene de resistência permite supor que existam homólogos deste gene em diferentes espécies de plantas, mesmo que por meio de modificações ao longo da evolução estes tenham adquirido outras especificidades e sejam incapazes de ativar o processo de defesa para um mesmo patógeno. A presença de homólogos dentro da família Solanaceae (tomateiro, fumo, batata e berinjela) foi demonstrada para o gene $B s 2$ (da mesma classe que 

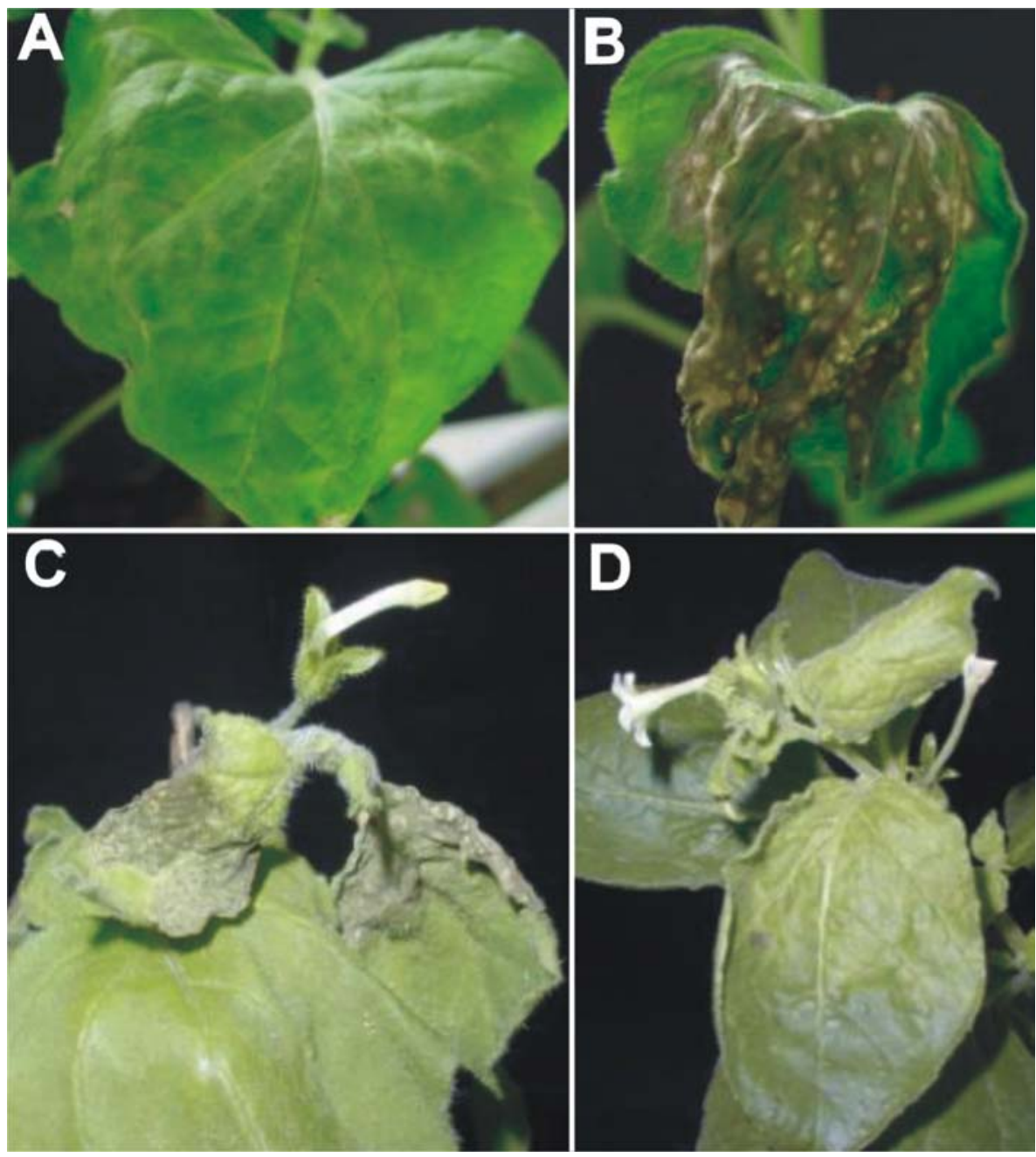

FIG. 3 - Sintomas observados em plantas de Nicotiana benthamiana inoculadas com tospovírus. A. Lesões cloróticas em folhas inoculadas de plantas não transformadas. B. Resposta de hipersensibilidade em folha de planta transformada com $S w-5$. C. Necrose sistêmica em planta transformada com $S w$-5. D. Clorose e deformação foliar, sintomas sistêmicos induzidos por tospovírus em plantas não transformadas.

Sw-5), originário da pimenta (Capsicum chacoense Hunz.) e capaz de desencadear HR nestas espécies (Tai et al., 1999). A presença de homólogos de $S w-5$ foi demonstrada em Capsicum spp. (Jahn et al., 2000), no entanto, estes não conferem resistência a tospovírus.

A análise da evolução de genes de resistência dentro da família Solanaceae mostra que a especificidade de reconhecimento do patógeno pode estar evoluindo rapidamente, enquanto mantém-se conservada a capacidade de desencadear as respostas de defesa. Esta hipótese é baseada na observação de que genes homólogos, ocupando a mesma posição no genoma, podem conferir resistência a patógenos diferentes (Grube et al., 2000). Em diferentes espécies de tomateiro, genes homólogos podem ser amplificados por meio de PCR com oligonucleotídeos baseados na sequência de $S w-5$ (Lima, 2001). Utilizando-se oligonucleotídeos que pareiam na região 5' de $S w-5$, observa-se a amplificação de fragmentos de tamanho esperado em $N$. tabacum, $N$. benthamiana, berinjela e batata (dados não mostrados).

Acomparação entre o espectro da resistência conferida por $S w-5$ em $N$. benthamiana com o observado em tomate, berinjela e $N$. tabacum indica haver uma equivalência nestes sistemas. O isolado V1-3, causador de necrose sistêmica em $N$. benthamiana, induz necrose sistêmica em tomateiro heterozigoto para o gene $S w-5$ e também causa infecção sistêmica em fumo transgênico (Lau, 2001). Além disso, as lesões observadas nas folhas inoculadas com V1-3, que se distinguem da HR bem definida observada para os outros isolados, podem ser comparadas às lesões necróticas com anéis concêntricos observadas em berinjela (Lima et al., 2000). Assim, em sistemas heterólogos parece haver um deslocamento da resistência para níveis mais baixos, em que a tendência de um isolado em causar infecção sistêmica em plantas com $S w-5$ torna-se mais pronunciada. Um dos fatores 
TABELA 2 - Frequência dos diferentes sintomas exibidos por plantas de Nicotiana benthamiana não transformadas e plantas da progênie B5-5 inoculadas com quatro isolados de tospovírus

\begin{tabular}{|c|c|c|c|c|c|c|c|c|}
\hline \multirow{4}{*}{ Sintomas } & \multicolumn{8}{|c|}{ Plantas inoculadas } \\
\hline & \multirow{2}{*}{\multicolumn{4}{|c|}{$\begin{array}{c}\begin{array}{c}N . \text { benthamiana } \\
\text { (Não transformada) }\end{array} \\
\text { Isolados }\end{array}$}} & \multirow{2}{*}{\multicolumn{4}{|c|}{$\begin{array}{c}\text { B5-5 } \\
(S w-5 / S w-5) \\
\text { Isolados }\end{array}$}} \\
\hline & & & & & & & & \\
\hline & V1-3 & V2-2 & $\mathbf{A L}$ & $\mathrm{Cb}$ & V1-3 & V2-2 & $\mathbf{A L}$ & $\mathbf{C b}$ \\
\hline HR & $0 / 7 *$ & $0 / 10$ & $0 / 5$ & $0 / 6$ & $10 / 10$ & $10 / 10$ & $10 / 10$ & $10 / 10$ \\
\hline $\begin{array}{l}\text { Lesões cloróticas/ } \\
\text { Mosaico }\end{array}$ & $7 / 7$ & $10 / 10$ & $5 / 5$ & $6 / 6$ & $0 / 10$ & $0 / 10$ & $0 / 10$ & $0 / 10$ \\
\hline Necrose sistêmica & $0 / 7$ & $0 / 10$ & $0 / 5$ & $0 / 6$ & $10 / 10$ & $0 / 10$ & $0 / 10$ & $0 / 10$ \\
\hline
\end{tabular}

* Plantas com sintomas / Total de plantas inoculadas.

que pode afetar a resistência pode ser o nível de expressão do transgene, em que contribuem a posição de inserção deste no genoma e os elementos cis-regulatórios. O aumento da resistência verificado em uma progênie de fumo com duas inserções de $S w-5$ sob controle do promotor $35 \mathrm{~S}$ reforça a hipótese da relação entre nível de expressão e resistência (Yamazaki, 2001). Ainda quanto ao hospedeiro, a menor funcionalidade da proteína em sistema heterólogo e respostas de defesa menos eficientes devem ser consideradas. Estudos realizados em fumo (Lau, 2001; Yamazaki, 2001), em que plantas transformadas foram completamente suscetíveis a determinados isolados de tospovírus, não sendo observada $\mathrm{HR}$, reforçam a hipótese de que podem existir deficiências na funcionalidade da proteína $\mathrm{Sw}-5$ em sistemas heterólogos. Esses resultados podem ser explicados pela menor eficácia da interação da proteína $\mathrm{Sw}-5$ com os demais componentes das vias de transdução de sinais que ativam as respostas de defesa nesses sistemas. Esta hipótese é corroborada pela observação de que para alguns genes de resistência, dependendo da planta em que são expressos, diferentes quantidades da molécula elicitora são necessárias para o desencadeamento de HR. O gene $C f-9$, por exemplo, é capaz de desencadear HR em Brassica napus L., mas somente se quantidades do peptídeo elicitor Avr9 muito superiores às utilizadas em tomate (de onde o gene é originário) forem infiltradas nos tecidos (Hennin et al., 2001).

Em resumo, os resultados obtidos para Nicotiana benthamiana transformada com o gene $S_{w-5}$ indicam que a ORF deste gene contém toda informação necessária para codificar uma proteína capaz de desencadear o processo de defesa a tospovírus neste sistema heterólogo. Além disso, $N$. benthamiana, assim como outros membros da família Solanaceae, contém os componentes das vias de transdução de sinais e elementos de resposta de defesa a tospovírus ativados pela proteína $\mathrm{Sw}-5$. A comparação do espectro da resistência observado em $N$. benthamiana com o observado para outras solanáceas corrobora a hipótese de que polimorfismo genético nos componentes das vias de transdução de sinais pode resultar em diferentes níveis de resistência, mesmo no caso de genes de efeito principal.

\section{REFERÊNCIAS BIBLIOGRÁFICAS}

BAKER, B., ZAMBRYSKI, P., STASKAWICZ, B. \& DINESHKUMAR, S.P. Signaling in plant-microbe interactions. Science 276:726-733. 1997.

BELKHADIR, Y., SUBRAMANIAM, R. \& DANGL, J.L. Plant disease resistance protein signaling: NBS-LRR proteins and their partners. Current Opinion in Plant Biology 7:391-399. 2004.

BENDAHMANE, A., KANYUKA, K. \& BAULCOMBE, D.C. The $R x$ gene from potato controls separate virus resistance and cell death responses. Plant Cell 11:781-791. 1999.

BEZERRA, I.C., RESENDE, R.O., POZZER, L., NAGATA, T., KORMELINK, R., \& ÁVILA, A.C. Increase of tospoviral diversity in Brazil with the identification of two new tospovirus species, one from chrysanthemum and one from zucchini. Phytopathology 89:823-830. 1999.

BOITEUX, L.S. \& GIORDANO, L.B. Genetic basis of resistance against two Tospovirus species in tomato (Lycopersicon esculentum). Euphytica 71:151-154. 1993.

BROMMONSCHENKEL, S.H., FRARY, A., FRARY, A. \& TANKSLEY, S.D. The broad-spectrum tospovirus resistance gene $S w-5$ of tomato is a homolog of the root-knot nematode resistance gene Mi. Molecular Plant-Microbe Interactions 13:1130-1138. 2000 .

DURRANT, W.E. \& DONG, X. Systemic acquired resistance. Annual Review of Phytopathology 42:185-209. 2004.

FULTON, T.M., CHUNWONGSE, J. \& TANKSLEY, S.D. Microprep protocol for extraction of DNA from tomato and other herbaceous plants. Plant Molecular Biology Reporter 13:207-209. 1995.

GERMAN, T.L., ULLMAN, D.E. \& MOYER, J.W. Tospoviruses: diagnosis, molecular biology, phylogeny, and vector relationships. Annual Review of Phytopathology 30:315-348. 1992.

GRANT, M.R., GODIARD, L., STRAUBE, E., ASHFIELD, T., LEWALD, J., SATTLER, A., INNES, R.W. \& DANGL, J.L. Structure of the Arabidopsis $R P M 1$ gene enabling dual specificity disease resistance. Science 269:843-846. 1995.

GRUBE, R.C., RADWANSKI, E.R. \& JAHN, M. Comparative genetics of disease resistance within the solanaceae. Genetics 155:873-887. 2000.

HAMMOND-KOSACK, K.E. \& JONES, J.D.G. Resistance genedependent plant defense responses. Plant Cell 8:1773-1791. 1996.

HAMMOND-KOSACK, K.E., TANG, S., HARRISON, K. \& JONES, J.D.G. The tomato $C f-9$ disease resistance gene functions in tobacco and potato to confer responsiveness to the fungal avirulence gene product Avr9. Plant Cell 10:1251-1266. 1998.

HENNIN, C., HÖFTE, M. \& DIEDERICHSEN, E. Functional expression of $C f-9$ and $A v r 9$ genes in Brassica napus induces enhanced resistance to Leptosphaeria maculans. Molecular PlantMicrobe Interactions 14:1075-1085. 2001.

HUTCHESON, S.W. Current concepts of active defense in plants. Annual Review of Phytopathology 36:59-90. 1998.

JAHN, M. K., PARAN, I., HOFFMAN, K., RADWANSKI, E. R., LIVINGSTONE K. D. GRUBE, R.C., AFTERGOOT, E., LAPIDOT, M. \& MOYER, J. Genetic mapping of the Tsw locus for resistance to the Tospovirus Tomato spotted wilt virus in Capsicum 
Hipersensibilidade e necrose sistêmica em Nicotiana benthamiana...

spp. and its relationship to the $S w-5$ gene for resistance to the same pathogen in tomato. Molecular Plant-Microbe Interactions 13:673682. 2000 .

KARASAWA, M. Transformação de alface com o gene $S w-5$ originário de tomateiro e avaliação da resistência das plantas transgênicas a tospovírus. (Dissertação de Mestrado) Viçosa MG. Universidade Federal de Viçosa. 2001.

KUROZAWA, C., PAVAN, M.A. Doenças das Solanáceas. In: KIMATI, H., AMORIN, L. BERGAMIN FILHO, A., CAMARGO, L.E.A., REZENDE, J.A.M. (Eds.) Manual de Fitopatologia Doenças das Plantas Cultivadas. São Paulo. Agronômica Ceres. 1997. v. 2. pp. 665-675.

LAU, D. Análise de fatores que influenciam a resistência a tospovírus conferida pelo gene $S w-5$ em tomateiro e tabaco. (Dissertação de Mestrado) Viçosa, MG. Universidade Federal de Viçosa. 2001.

LIMA, G.S.A. Resistência a tospovírus, clonagem e caracterização molecular de alelos do loco Sw-5 em espécies de Lycopersicon. (Tese de Doutorado) Viçosa, MG. Universidade Federal de Viçosa. 2001.

LIMAG.S.A.,PICOLI,E.A.T.,LAU,D.,BROMMONSCHENKEL, S.H., OTONI, W.C. \& ZERBINI, F.M. Signal transduction pathways mediated by the Sw-5 are conserved in eggplant. Virus Reviews \& Research 5:191-192. 2000. (Abstract)

LIMA, G.S.A, LAU, D, PICOLI, E.A.T., ASSUNÇÃO, I.P., BROMMONSCHENKEL, S.H. \& OTONI, W.C. Reação de genótipos de berinjela a quatro espécies de tospovírus. Summa Phytopathologica 28:242-247. 2002.

MARTIN, G.B., BOGDANOVE, A.J. \& SESSA, G. Understanding the functions of plant disease resistance proteins. Annual Review of Plant Biology 54:23-61. 2003.

MILLIGAN, S.B., BODEAU, J., YAGHOOBI, J., KALOSHIAN, I., ZABEL, P., \& WILLIAMSON, V.M. The root knot nematode resistance gene $M i$ from tomato is a member of the leucine zipper, nucleotide binding, leucine-rich repeat family of plant genes. Plant Cell 10:1307-1319. 1998.

NIMCHUK, Z., EULGEM, T., HOLT III, B.F. \& DANGL, J.L. Recognition and response in the plant immune system. Annual Review of Genetics 37:579-609. 2003.

ORI, N., ESHED, Y., PARAN, I., PRESTING, G., AVIV, D., TANKSLEY, S., ZAMIR, D., \& FLUHR, R. The I2C family from the wilt disease resistance locus I2 belongs to the nucleotide binding, leucine-rich repeat superfamily of plant resistance genes. Plant Cell 9:521-532. 1997.

PICOLI, E.A.T. Morfogênese in vitro e transformação genética de berinjela (Solanum melongena L. cv. Embú) mediada por
Agrobacterium tumefaciens. (Dissertação de Mestrado) Viçosa MG. Universidade Federal de Viçosa. 2000.

ROMMENS, C.M.T., SALMERON, J.M., OLDROYD, G.E.D. \& STASKAWICZ, B.J. Intergeneric transfer and functional expression of the tomato disease resistance gene Pto. Plant Cell 7:1537-1544. 1995.

SALMERON, J.M., OLDROYD, G.E.D., ROMMENS, C.M.T., SCOFIELD, S.R., KIM, H.-S., LAVELLE, D.T., DAHLBECK, D. \& STASKAWICZ, B.J. Tomato Prf is a member of the leucine-rich repeat class of plant disease resistance genes and lies embedded within the Pto kinase gene cluster. Cell 86:123-133. 1996.

SPASSOVA, M.I., PRINS, T.W., FOLKERTSMA, R.T., KLEINLANKORST, R.M., HILLE, J., GOLDBACH, R.W. \& PRINS, M. The tomato gene $S w-5$ is a member of the coiled coil, nucleotide binding, leucine-rich repeat class of plant resistance genes and confers resistance to TSWV in tobacco. Molecular Breeding 7:151-161. 2001.

SOMSSICH, I.E. \& HAHLBROCK, K. Pathogen defence in plants - a paradigm of biological complexity. Trends in Plant Science 3:86-90. 1998.

STASKAWICZ, B.J., AUSUBEL, F.M., BAKER, B.J. ELLIS, J.G. \& JONES, J.D.G. Molecular genetics of plant disease resistance. Science 268:661-667. 1995.

STEVENS, M.R., SCOTT, S.J. \& GERGERICH, R.C. Inheritance of a gene for resistance to Tomato spotted wilt virus (TSWV) from Lycopersicon peruvianum Mill. Euphytica 59:9-17. 1992.

TAI, T.H., DAHLBECK, D., CLARK, E.T., GAJIWALA, P., PASION, P., WHALEN, M.C., STAHL, R.E. \& STASKAWICZ, B.J. Expression of the $B s 2$ pepper gene confers resistance to bacterial spot disease in tomato. Proceedings of National Academy of Science of the USA 96:14153-14158. 1999.

THILMONY, R.L., CHEN, Z., BRESSAN, R.A. \& MARTIN, G.B. Expression of the tomato Pto gene in tobacco enhances resistance to Pseudomonas syringae pv. tabaci expressing avrPto. Plant Cell 7:1529-1536. 1995.

VAN DER HOORN, R.A.L., LAURENT, F., ROTH, R. \& DE WIT, J.G.M. Agroinfiltration is a versatile tool that facilitates comparative analyses of Avr9/Cf-9-induced and Avr4/Cf-4-induced necrosis. Molecular Plant-Microbe Interactions 13:439-446. 2000.

YAMAZAKI, E. Resistência de tabaco e alface transformados com o gene $S w-5$, sob o controle do promotor $35 \mathrm{~S}$, a três espécies de tospovírus. (Dissertação de Mestrado) Viçosa MG. Universidade Federal de Viçosa. 2001.

WHITHAM, S., McCORMICK, S. \& BAKER, B. The $N$ gene of tobacco confers resistance to Tobacco mosaic virus in transgenic tomato. Proceedings of National Academy of Science of the USA 93:8776-8781. 1996. 